REC-WP 03/2011

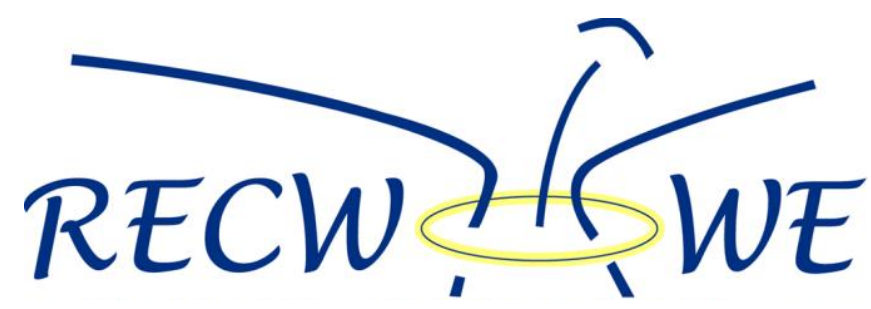

Working Papers on the Reconciliation of Work and Welfare in Europe

\title{
The dependent variable problem in quantitative studies of Active Labour Market Programmes:
}

\section{Uncovering hidden dynamics?}

Timothee Vlandas 

Timothee Vlandas

The dependent variable problem in quantitative studies of Active Labour Market Programmes. Uncovering hidden dynamics?

\section{REC-WP 03/2011}

Working Papers on the Reconciliation of Work and Welfare in Europe RECWOWE Publication, Dissemination and Dialogue Centre, Edinburgh

(c) 2011 by the author(s)

The Working Papers on the Reconciliation of Work and Welfare in Europe series seeks to promote the diffusion of research and research integration activities taking place within the network and being produced by other researchers working on issues of work and welfare in Europe.

Working papers are published either within the framework of a series of closed calls, which follow the different stages in the life-cycle of the network's activities, or as part of an open call, which aims to privilege both research focussed on cross-national comparative analysis of the various tensions between work and welfare and research focussed on the role of the European level in addressing these tensions.

All papers are peer-reviewed.

The Working Papers on the Reconciliation of Work and Welfare in Europe are published online by the Publication, Dissemination and Dialogue Centre (PUDIAC) of RECWOWE. They can be downloaded at

http://www.socialpolicy.ed.ac.uk/recwowepudiac/working papers/

RECWOWE / PUDIAC on the internet: http://www.socialpolicy.ed.ac.uk/recwowepudiac 


\section{About the author}

Tim Vlandas is a PhD Candidate at the European Institute at the London School of Economics. He is a graduate of the LSE and the School of Oriental African Studies (London) where he completed an MSc in European Political Economy and an MSc in Development Economics. His thesis focuses on the political economy of disaggregated Active Labour Market Programs and his research interests are on EU welfare state reforms, the political economy of Labour market policies, and the dualisation of European Labour markets. 


\section{Abstract}

The question of what explains variation in expenditures on Active Labour Market Programs (ALMPs) has attracted significant scholarship in recent years. Significant insights have been gained with respect to the role of employers, unions and dual labour markets, openness, and partisanship. However, there remain significant disagreements with respects to key explanatory variables such the role of unions or the impact of partisanship.

Qualitative studies have shown that there are both good conceptual reasons as well as historical evidence that different ALMPs are driven by different dynamics. There is little reason to believe that vastly different programs such as training and employment subsidies are driven by similar structural, interest group or indeed partisan dynamics. The question is therefore whether different ALMPs have the same correlation with different key explanatory variables identified in the literature? Using regression analysis, this paper shows that the explanatory variables identified by the literature have different relation to distinct ALMPs. This refinement adds significant analytical value and shows that disagreements are at least partly due to a dependent variable problem of 'over-aggregation'.

\section{Keywords}

Labour market policy, active labour market policies, ALMP, political economy 


\section{Introduction ${ }^{1}$}

The question of what drives welfare state changes and policies has interested scholars for some time now. This paper aims to contribute to this debate by looking at the determinants of Active Labour Market Policies (ALMPs). ALMPs are policies financed by the government with the purpose of reducing unemployment and include spending on programs such as training, employment subsidies and public employment services. This focus is relevant for at least three reasons.

First, labour markets are political arenas par excellence given their importance for labour, capital and governments. Second, the activation paradigm ${ }^{2}$ in which these policies are embedded has gained particular importance in European Member States' reform agenda. This is particularly obvious in the increased prescriptive emphasis that international organisations such as the European Union (EU) and the Organisation for Economic Cooperation and Development (OECD) have put on activation, but also empirically as many EU countries have implemented activation reforms in their labour market policies. Third, not surprisingly given the previous two reasons, a growing and substantial literature has looked at the determinants of ALMPs.

This is especially clear with respect to the literature undertaking quantitative analyses. While in the 1990s, only Boix (1998) and Janoski and Hicks (1994) analysed quantitatively the determinants of ALMPs, the 2000s were marked by a growing number of studies (Martin and Swank 2004; Rueda 2006; Rueda 2007; Swank 2007; Huo, Nelson et al. 2008; Van Vliet and Koster 2008). Yet, as Bonoli (2008: abstract) notes: "we seem to be far from a satisfactory account of the determinants of active labour market policy".

A major point of disagreement surrounds the question of whether left parties are positively related to ALMPs, as these are presumed to favour labour, or whether left parties only represent the interests of insiders, not outsiders, and hence will not support ALMPs, unless certain conditions are met, such as low employment protection or inclusive unions. The conditions under which trade unions will support ALMPs (Nelson, 2006), and whether this support will translate in higher spending, are similarly contested. Despite the diversity of approaches, these studies share the shortcoming that they rely on an indicator which is too broad and hence incorporates theoretically and empirically distinct dynamics. Indeed, there is little reason to presume that training, spending on public employment services, and employment subsidies, to name but three types of programs classified as ALMPs, are driven by similar dynamics.

The research question of this paper is therefore twofold. First, do different ALMPs have the same empirical relations with different key explanatory variables identified in the literature? Second, if the answer to this empirical question is no, what then are the theoretical implications of these different relationships? In light of the qualitative literature and the existing conflicting results in the large $\mathrm{N}$ literature, the expectation is that different ALMPs have different relationships with the main determinants that the literature has identified. This paper therefore argues that it is problematic to use aggregate ALMPs as a dependent variable in quantitative studies. There are no clear prior expectations with respect to the determinants of specific ALMPs. Hence, with respect to the second question this paper proceeds 
inductively with the aim, where possible, to reconcile the disagreements of the existing literature.

The next section reviews the literature relying on quantitative methods. Section III shows that qualitative studies indicate different types of ALMPs are driven by different dynamics. The fourth section starts by undertaking descriptive empirical analysis of different ALMPs. Different regression methods are then employed to establish the relation between different ALMPs and the main explanatory variables identified in the existing literature. Before concluding, the results of the regression analysis are discussed and some theoretical implications are identified.

\section{Quantitative literature review}

Quantitative studies of the determinants of ALMPs share similar approaches (most often panel data regressions analysis) regressing aggregate spending on ALMPs as a percentage of GDP or total labour market expenditures, sometimes weighted with a proxy for the unemployment level. Table 1 briefly summarises the quantitative effects of different determinants on the spending levels of ALMPs that have been identified by the literature ${ }^{3}$. One can observe quite important differences concerning the impact of key variables for theories of what drives welfare state change: (A) Partisanship, (B) Trade unions and coordination, and $(\mathrm{C})$ Openness, europeanization, and deindustrialisation.

\section{A: Partisanship}

The debate has been centred particularly strongly on the role of partisanship, where the latter is often operationalised in line with earlier literature (Huber and Stephens 2001) by calculating the cabinet share of different parties, though other authors (for instance: Bonoli 2008) have relied on parliamentary representation. On the one hand, authors find that spending on ALMPs is positively influenced by the presence of social democratic and left wing parties in government (Boix 1998; Swank and Martin 2001; Swank 2007; Huo, Nelson et al. 2008). The idea is that social democratic parties' traditional concern for employment implies that they would embrace activation insofar as it promotes employment and hence the interests of labour. The prototypical illustration of this is the active labour market policy undertaken by Sweden under social democratic rule (Esping-Andersen 1990). From this perspective, other left leanings actors such as unions are also expected to support these expenditures on activation programs as this strengthens unions' bargaining strength through lower unemployment.

On the other hand, partisanship is not found to be significant in a number of studies (for instance: Gaston and Rajaguru 2008; Dahlström, Lindvall et al. 2009) and Bonoli (2008) finds left parties to have a negative significant effect on ALMPs, while the coefficient on the interaction variable between openness and left parties is positive. Similarly, Rueda (2007) finds that activation spending is not (or negatively) affected by social democratic parties. The argument is that labour is not homogenous and can be divided into labour market insiders (those with regular full time employment) and outsiders (the unemployed and workers in involuntary part time and temporary employment). In this theory, the interests of these two 
groups are different because "insiders care about their own employment protection much more than about labour market policies aimed at promoting the interests of outsiders" (ibid: 212). Social democratic parties are concerned only about insiders as their core constituency and not about ALMPs' main target group (i.e.: outsiders). As a result, they are either neutral or opposed to activation, except where employment protection of insiders is low, thereby making insiders more like outsiders.

If left wing parties do not promote ALMPs, then that begs the question of who is promoting it? The impact of right wing parties in government is similarly contested: Franzese and Hays (2006) find that Christian democratic parties have no significant effect, Dahstrom et al (2009) and Bonoli (2008) find a significant positive effect, and Swank and Martin (2010) a negative effect. It is not clear theoretically why right wing parties should themselves be preoccupied with the interests of labour market outsiders which are not one of their core constituencies.

\section{B: Trade unions and coordination}

Trade unions are found to be positively related to ALMPs in a number of studies (Rueda 2006; Gaston and Rajaguru 2008; Dahlström, Lindvall et al. 2009; Traxler and Brandl 2009). The expectation that unions would support ALMPs stems partly from their traditional position towards social policies that expand the welfare state's reach. However, union's support can occur for quite different reasons and through different causal mechanisms: they could do so because it favours labour in line with classic power resource theory (Korpi 1978), because it allows them to extend their membership base (Clegg, Graziano et al. 2010), because there are many labour market outsiders in unions as a result of high union density or because insiders are more like outsiders when employment protection legislation is low (Rueda 2007). In line with this latter purported mechanism, employment protection for regular workers is found to have a negative effect.

Union support for ALMPs may itself be conditional on other factors. For instance, Nelson (2009: 230) finds that support "increase in contexts of rapid deindustrialization and low employment protection" and decreases with "high unemployment". Support is also likely to be higher where "union membership is more encompassing" (Nelson 2006: 1). Moreover, in their model Franzese and Hays (2006) do not find union density to have a significant effect, and Rueda (2007) similarly does not find a positive significant relationship. One explanation has underscored the possibility that unions may not have incentives to support ALMPs. Non-working labour market outsiders have much smaller unionisation rates than workers in employment (Ebbinghaus 2006). Given their overall tendency to be under represented among unions, they will only be represented insofar as it does not adversely affect insiders' interests. But this is unlikely to be the case. As Rueda (2007: 26) argues, to the extent that ALMPs are funded out of taxes that fall on insiders and may increase labour market competition, insiders may oppose ALMPs.

More generally, it is also possible to analyse the effect of the structure in which unions operate. For instance, the degree of coordination, using a number of different measures, is found to be positively associated with ALMPs, though there is some variation in the type of coordination which is found to be significant. Swank's results (2007) identify only sector 
coordination as significant, not national coordination. Van Vliet and Koster (2008) finds a significant coefficient for tripartite council significant, while for Dahlstrom et al (2009) finds that bargaining coordination has a positive significant effect and Traxler and Brandl's (2009) results confirm this. Only Rueda's results for coordination are not significant (Rueda 2006; 2007). Last, employers' influence, especially as measured by their degree of organisation, has a positive significant effect on ALMPs expenditures (Swank and Martin 2001; and 2004).

\section{C: Openness and Europeanization, or Deindustrialisation?}

Openness has most often a positive effect on ALMPs, but three studies find it to have no significant effect (Gaston and Rajaguru 2008; Huo, Nelson et al. 2008; Van Vliet and Koster 2008) and one article finds a negative effect (Martin and Swank 2004). The positive effect is consistent with the notion that ALMPs can be used to ensure the adaptability of labour markets to the pressures that openness imposes on the level of competitiveness of countries (Katzenstein 1985) and with the seminal findings of Cameron (1978: 71) which pointed to the fact that "nations with open economies were far more likely to experience an increase in the scope of public funding". More recently, Garrett (1995; 1998) and Rodrik (1998) have also shown that higher levels of openness increase the size of the welfare state because "government spending plays a risk-reducing role in economies exposed to a significant amount of external risk (Rodrik 1998: 997).

Studies that have looked at EU dynamics find that EU membership has a positive effect while European Monetary Union (EMU) membership has a negative effect on ALMPs (Armingeon 2005 and 2007; Swank 2007; Van Vliet and Koster 2008). More specifically, the European Employment Strategy is positively related to a stronger emphasis on ALMPs as percentage of total labour market spending in EU member states (Van Vliet and Koster 2008: 17) either because of learning between European policy makers or as result of the effect of recommendations (De la Porte and Nanz 2003; Zeitlin and Pochet 2005), while membership in EMU may constrain budget thereby affecting expenditures on ALMPs (ibid: 18).

That openness is a driving force behind the expansion of the welfare state has also been contested on the basis that it is deindustrialisation that is the most relevant explanatory factor for aggregate spending on the welfare state (Iversen and Cusack, 1998). Deindustrialisation is found to have a significant positive effect in the three out of four studies where it is considered (Martin and Swank 2004; Franzese and Hays 2006; Swank 2007)4. In one case (Swank and Martin 2010: table 7), it is significant as an interaction effect with employers' organisations but not on its own. This is consistent with the earlier finding that "deindustrialization poses significant risks that can be addressed only through government expansion of social security" (Iversen and Cusack 1998: 346) as deindustrialisation "should mean that service sector firms have a greater need for training than manufacturing firms" (Martin and Swank 2004: 597). 


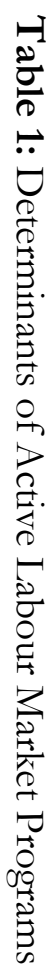

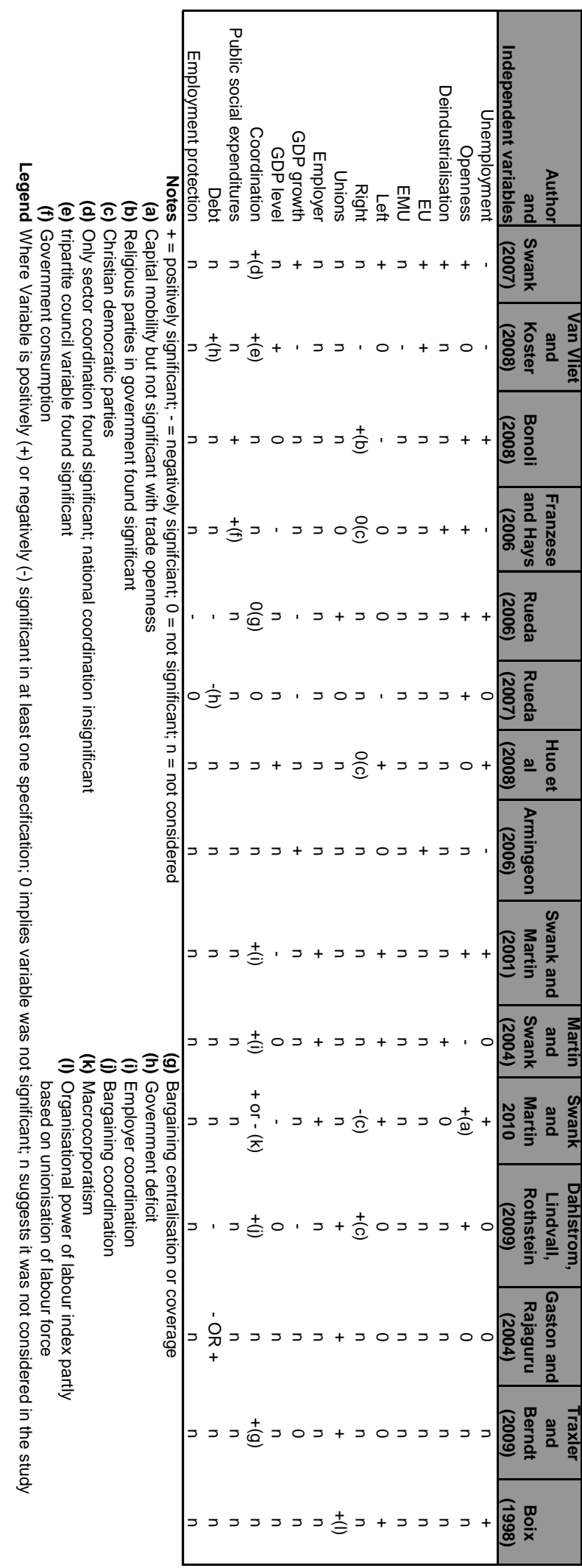




\section{Qualitative literature review}

Thus, what drives activation spending remains an open question from an empirical (large N) perspective. Partly this may result from a false premise concerning the presumed effectiveness of the programs, whereas a number of ALMPs are actually unable to reduce unemployment (Martin and Grubb 2001) and the evidence has been contested (Calmfors, Forslund et al. 2001).

This points to the possibility that ALMPs as a category is too broad which makes "it difficult to use the notion of ALMPs as an analytical tool" (Bonoli 2010: 22). Using as a dependent variables aggregate spending on ALMPs may put together programs which are sufficiently heterogeneous to be expected to be driven by different dynamics. This expectation is based on the historical evidence concerning the drivers of different ALMPs.

Earlier work, most notably the welfare regime typologies pioneered by Esping-Andersen (1990), had shown why the power of the labour movement and their political representatives were able in social democratic Scandinavia to develop effective ALMPs. This was instrumental in promoting one of labour's key objectives such as minimising unemployment and achieving full employment. The notion that labour was the only or indeed the main driving force behind these developments has been contested by Swenson (1991: 542, 543; and Swenson 2002): "The cross-class political realignment that brought Social Democrats in Denmark and Sweden to power ... included sub political alliances of union and employer groups behind centralized control of industrial relations and the intersectoral structure of pay.“

However, qualitative contributions have also underscored the notion that there are different worlds or types of activation of labour market policies (Torfing 1999; Barbier 2001; Barbier and Ludwig-Mayerhofer 2004; Taylor-Gooby 2004) and that activation may not be a homogenous process. These authors share a common argument that activation at the very least entails two types of processes, if not more. Bonoli (2010: 440 and 441) goes further and distinguishes four types of activation: "incentive reinforcement" includes "measures that aim to strengthen work incentives for benefit recipients", "employment assistance" refers to "measures aimed at removing obstacles to labor-market participation", "occupation" aims to "keep jobless people busy, to prevent the depletion of human capital associated with an unemployment spell" and "upskilling" consists of "vocational training".

He then operationalizes the latter three measures (i.e.: employment assistance, occupation, and upskilling) using OECD data for six European countries: Denmark, Sweden, Germany, France, the United Kingdom and Italy. The evolution of policies are analysed across three periods of time: the postwar years (from the 1950s to the 1970s), ALMPs in the context of mass unemployment (from the 1970s to the early 1990s) and the "activation turn" (since the mid-1990s). The evidence suggests that different actors support different measures. As Bonoli (2010: 452) concludes: "there is little regularity across time and space of the political forces that are behind major ALMP initiatives". For instance, investment in human capital was supported by both Christian and social democrats while liberal as well as Conservative parties emphasised the reinforcement of incentives. 
Hence, while a given actor, such as unions, may support certain measures such as training, they may oppose the introduction of other measures, for instance employment incentives. If both are included under the same spending figure, this may lead to spurious associations between activation spending and explanatory variables. In sum, there are both empirical (diverse results in the literature) as well as historical reasons to doubt that all ALMPs are driven by similar dynamics. The next section proceeds with an empirical analysis of the dependent and independent variables.

\section{Empirical analysis}

The OECD statistics website provides disaggregated data on spending on seven types of ALMPs: (1) public employment services and administration (placement and related services, benefit administration); (2) training (institutional training, workplace training, integrated training, special support for apprenticeship); (3) job rotation and job sharing; (4) employment incentives (recruitment incentives and employment maintenance incentives); (5) supported employment and rehabilitation; (6) direct job creation; and (7) start up incentives. This categorisation follows from the new classification as introduced by Eurostat in 1998 which the OECD has decided to take up from 2002 onwards (Grubb and Puymoyen 2008). ${ }^{5}$

Throughout, I rely on a sample of fifteen European countries (i.e.: EU15 minus Luxembourg plus Norway) over the period 1985 to 2007, though data availability varies depending on variables and countries. In this section I focus on categories (1), (2), (4), (5) and (6) for reasons of parsimony, but also because category (3) relates to maintaining people in jobs and has limited data availability while category (7) promotes self-employment rather than dependent employment. This section first undertakes basic correlation analysis to show how the dependent variables relate to one another and their degree of correlation with key explanatory variables. Then, it presents the basic regression model and estimation strategy before discussing the results.

\section{A: Correlation analysis}

As shown in Table 2, some of these variables are indeed correlated. For instance, spending on employment incentives and training has a significant positive correlation equal to 0.51 while spending on employment incentives and supported employment and rehabilitation have a significant positive correlation coefficient of 0.29 . The highest significant correlation is between Public Employment Services (PES) and supported rehabilitation (0.73). However, employment incentives and direct job creation have a non-significant coefficient of a small magnitude (0.07). Employment incentives similarly have a very low non-significant correlation with PES (0.0031). While the correlation between direct job creation and supported rehabilitation is significant, the coefficient is low at about 0.09 . It is therefore very unlikely that direct job creation is driven by similar dynamics as employment incentives and supported rehabilitation, or that PES shares the same determinants as supported rehabilitation. 


\begin{tabular}{cccccc} 
& Training & $\begin{array}{c}\text { Employment } \\
\text { incentives }\end{array}$ & $\begin{array}{c}\text { Supported } \\
\text { rehabilitation }\end{array}$ & $\begin{array}{c}\text { Direct job } \\
\text { creation }\end{array}$ & $\begin{array}{c}\text { Public } \\
\text { Employment } \\
\text { services }\end{array}$ \\
\hline Training & 1 & $0.5198^{* * *}$ & $0.2967^{* * *}$ & $0.2214^{* * *}$ & $0.1380^{* *}$ \\
Employment incentives & $0.5198^{* * *}$ & 1 & $0.2994^{* * *}$ & 0.0763 & 0.0031 \\
Supported rehabilitation & $0.2967^{* * *}$ & $0.2994^{* * *}$ & 1 & $0.0926^{* *}$ & $0.7336^{* * *}$ \\
$\begin{array}{c}\text { Direct job creation } \\
\text { Public Employment }\end{array}$ & $0.2214^{* * *}$ & 0.0763 & $0.0926^{* *}$ & 1 & $0.1939^{* * *}$ \\
$\quad$ Services & $0.1380^{* *}$ & 0.0031 & $0.7336^{* * *}$ & $0.1939^{* * *}$ & 1
\end{tabular}

Table 2: Correlation between various ALMPs

Note: ${ }^{*} p<.1 ; * * p<.05 ; * * *<<.01$

\begin{tabular}{|c|c|c|c|c|c|c|}
\hline $\begin{array}{c}\text { ALMPs / } \\
\text { determinants }\end{array}$ & ALMPs & Training & $\begin{array}{l}\text { Employm. } \\
\text { incentives }\end{array}$ & $\begin{array}{l}\text { Supported } \\
\text { rehabilitation }\end{array}$ & $\begin{array}{l}\text { Direct job } \\
\text { creation }\end{array}$ & $\begin{array}{c}\text { Public } \\
\text { Employment } \\
\text { services }\end{array}$ \\
\hline Deindustrialisation & $0.4758 * * *$ & $0.2251 * * *$ & $0.2322 * *$ & $0.4758^{* * *}$ & $0.2306^{* * *}$ & $0.5172 * * *$ \\
\hline Deficit & $-0.0013^{* * *}$ & -0.0164 & -0.0091 & 0.0558 & -0.0075 & -0.0447 \\
\hline Openness & $0.2583^{* * *}$ & -0.0342 & -0.0603 & $0.3285^{* * *}$ & $0.4628 * * *$ & $0.3708^{* * *}$ \\
\hline $\begin{array}{c}\text { Harmonised } \\
\text { unemployment }\end{array}$ & -0.0260 & 0.0058 & -0.0409 & $-0.3541 * * *$ & $-0.1714 * * *$ & $-0.1543^{* * *}$ \\
\hline Union density & $0.4860 * * *$ & $0.5167 * * *$ & $0.4667 * * *$ & $0.2540 * * *$ & $0.2048^{* * *}$ & -0.0346 \\
\hline Party in power & $0.0266 * * *$ & 0.0137 & 0.0681 & -0.0301 & -0.0745 & 0.0161 \\
\hline
\end{tabular}

Table 3: Introducing previous explanations on disaggregated data

Note: ${ }^{*} p<.1 ; * * p<.05 ; * * *<<.01$

Table 3 considers the correlation coefficients between these five ALMPs and the determinants identified in the literature, where they are defined as follows. Deindustrialisation is proxied by the usual formula as 100 minus the share of employees in services and agriculture (Iversen and Cusack 1998). Deficits are expressed as a percentage of GDP. Following other authors (for instance: Martin and Swank 2004; Bonoli 2008), openness has been computed as the sum of exports and imports divided by the GDP. Harmonised unemployment comprises the number of unemployed people as a percentage of the civilian labour force. Union density refers to net union membership as a proportion of wage and salary earners in employment. Last, party in power is an updated version of the Schmidt index which calculates the composition of the Cabinet composition. The coding is from (1) hegemony of right-wing (and centre) parties (gov_left=0) through to (5) hegemony of social- 
democratic and other left parties (gov_left=100), which is taken from the comparative political dataset (Armingeon, Gerger et al. 2008).

Looking at the results of the correlation analysis, a number of determinants have correlation coefficients with similar signs but rarely with the same magnitude. Deindustrialisation is significantly and positively correlated with all measures, and the correlation is particularly strong for supported rehabilitation (0.47) and PES (0.5172) but not for the other measures (around 0.2). Union density has a consistent significant positive correlation with all types of ALMPs, except for PES, but the range varies from 0.51 in the case of training to 0.20 in the case of direct job creation, suggesting that the importance of unions' membership varies between different programs. Partisanship (left parties in government) is not significantly correlated with any of the ALMPs under consideration, though the aggregate measure of ALMPs is significantly correlated with partisanship.

Moreover, variables identified in the literature have correlation coefficients which signs differ depending on the measure under consideration. For instance, deficit is not significantly correlated with the variables under consideration; and while the correlation is positive for supported rehabilitation, it is negative for the other variables. Openness has a significant positive impact on job creation and supported rehabilitation but negative and non-significant correlations with training and employment incentives. Harmonised unemployment has a nonsignificant positive correlation with training and employment incentives, but is negatively correlated with direct job creation. One could argue however that these apparent differences between the determinants of different programs are a result of the rather crude correlation analysis and that should one take a more sophisticated approach with the appropriate controls, this would not be the case. Thus, we now turn to regression analysis.

\section{B: The model}

As in the previous correlation analysis the sample covers 15 European countries in the period 1985 to 2007 which, given certain missing observations in my dataset, results in about 230 observations. The dependent variables throughout the analysis are disaggregated ALMPs data expressed as a percentage of GDP. Panel data regression analysis of five dependent variables is used to investigate whether the previously identified explanatory variables have consistently different effects on spending on different programs. The regression model that is tested is as follows:

$$
\mathrm{y}_{\mathrm{k}, \mathrm{it}}=\beta_{0}+\sum_{\mathrm{j}} \beta_{\mathrm{j}} \mathrm{x}_{\mathrm{j}, \mathrm{it}}+\sum_{\mathrm{p}} \gamma_{\mathrm{p}} \mathrm{z}_{\mathrm{p}, \mathrm{it}}+\delta_{\mathrm{i}}+\alpha_{\mathrm{t}}+\varepsilon_{\mathrm{i}, \mathrm{t}}
$$

where $y_{k, j}$ is the dependent variable $k$ in country $i$ at time t, the $x$ 's are $j$ explanatory variables, the $z$ 's are $\mathrm{p}$ controls, the $\delta_{\mathrm{i}}$ are $\mathrm{n}-1$ country specific effects, the $\alpha_{\mathrm{t}}$ 's are t-1 year dummies ${ }^{6}$ and $\varepsilon_{i, t}$ is the random residual. The dependent variable concerns the specific ALMPs under consideration expressed as a percentage of GDP. 
More specifically, the vector of explanatory variables is the following: $\sum_{\mathrm{j}} \beta_{\mathrm{j}} \mathrm{x}_{\mathrm{j}, \mathrm{it}}=\beta_{1}$ OPEN $_{\mathrm{i}, \mathrm{t}}+\beta_{2}$ DEIND $_{\mathrm{i}, \mathrm{t}}+\beta_{3}$ GOVPARTY $_{\mathrm{i}, \mathrm{t}}+\beta_{4}$ DEN $_{\mathrm{i}, \mathrm{t}}+\beta_{5} \mathrm{WCOORD}_{\mathrm{i}, \mathrm{t}}+\beta_{6}$ EPL $_{\mathrm{i}, \mathrm{t}}$

where OPEN is the degree of openness, DEIND is deindustrialisation, DEN the union density, GOVPARTY the measure of partisanship, all defined as in the previous section. Recall that the variable 'govparty' is coded from 1, where there is hegemony of right wing parties in government, through to 5 where there is hegemony of social democratic and other left parties in government. Thus, a negative coefficient means that there is an inverse relationship between left parties and the dependent variable. Thus, these variables are selected because there are key explanatory variables that the existing literature has analysed. The variable WCOORD stands for the degree of wage coordination and is coded from 1 which corresponds to fragmented (mostly at company) bargaining to 5 which stands for economywide bargaining, based on enforceable agreements between the central organisations (See the variable description of Armingeon, Gerger et al. 2008 for more details on these variables). The variable EPL is the overall index of Employment Protection Legislation (EPL) developed by the OECD, which was used by Rueda (2007) when investigating empirically his insideroutsider model. Last but not least, note that Europeanization that was discussed in part 2 of the paper is not included in this analysis on disaggregated data. This is because the sample is restricted almost exclusively to EU countries and hence is not appropriate to draw inferences concerning the effect of EU membership.

The vector of control variables includes: $\sum_{\mathrm{p}} \gamma_{\mathrm{p}} \mathrm{z}_{\mathrm{p}, \mathrm{it}}=\gamma_{1} \mathrm{GDP}_{\mathrm{i}, \mathrm{t}}+\gamma_{2} \mathrm{HU}_{\mathrm{i}, \mathrm{t}}+\gamma_{3} \mathrm{DEF}_{\mathrm{i}, \mathrm{t}}$ where GDP is GDP growth and is included because higher growth of GDP may affect both the cyclical and the discretionary component of policies; HU is harmonised unemployment which controls for the level of unemployment that ALMPs are supposed to address and DEF is the deficit as a percentage of GDP, which captures the constraints on budget that governments face.

As my dependent variables are time series expressed in levels, it is necessary to test for stationarity. Indeed, if both the dependent and the independent variables are non-stationary, then regression analysis may yield spurious results (Gujarati 2003). When including a trend, the null hypothesis is rejected for all dependent variables except direct job creation. With respect to the independent variables, including a time trend does not remove non-stationarity for the unemployment rate, union density and deindustrialisation. Thus, these three variables may become spuriously related to direct job creation as they both are non-stationary. As a result, particular attention will be paid to the regression with direct job creation, and first difference will also be calculated to ensure the results are not driven by non-stationarity. Last but not least, a Hausman test confirmed that random effects should be used to estimate this model (Hausman 1978) as the null hypothesis that random effects and fixed effects coefficients are the same is not rejected.

\section{C: Estimation strategy}

I first run a general model using the Feasible Generalised Least Square (FGLS) regression method with fixed effects, year dummies and a trend. Results are reported in Table 4. This allows me to further confirm whether random effects should be used and to carry out tests on 
the residuals. Different columns represent regressions using the same method on the same data but using a different dependent variable. Unless specified otherwise, the dependent variables are expressed in levels of expenditures as a percentage of GDP.

\begin{tabular}{|c|c|c|c|c|c|c|}
\hline Method & General Least & Squares, count & $y$ and time dum & mies no ar(1) pr & ocess, no treno & \\
\hline Dependent variable & ALMPs & Training & $\begin{array}{l}\text { Employment } \\
\text { incentives }\end{array}$ & $\begin{array}{l}\text { Supported } \\
\text { employment } \\
\text { rehabilitation }\end{array}$ & $\begin{array}{c}\text { Direct job } \\
\text { creation }\end{array}$ & \begin{tabular}{|c|} 
Public \\
Employment \\
services
\end{tabular} \\
\hline Explanatory Variables & 1 & II & III & N & v & VI \\
\hline Degree of trade openess & -0.0026901 & -0.0014034 & -0.0003873 & -0.0001322 & -0.0010214 & -0.0012099 \\
\hline & 0.0022246 & 0.0009541 & 0.0006909 & 0.000443 & 0.0007957 & 0.0005295 \\
\hline Deindustrialisation & 0.0069934 & -0.002876 & -0.0010643 & 0.0009661 & $0.0082163^{*}$ & 0.0033381 \\
\hline & 0.012017 & 0.0052027 & 0.0037672 & 0.0024155 & 0.0043388 & 0.0028602 \\
\hline Left government & -0.0080096 & -0.0028862 & -0.0084601 & $-0.003808^{*}$ & -0.0021587 & 0.0043904 \\
\hline & 0.0093188 & 0.0043478 & 0.0031464 & 0.0020174 & 0.0036238 & 0.003393 \\
\hline Union density & .0357067 & 0.010928 & 0.0039504 & 0.0020062 & 0.0134594 & 0.0062007 \\
\hline & 0.007784 & 0.0036597 & 0.002647 & 0.0016972 & 0.0030486 & 0.0018527 \\
\hline Degree of wage coordination & 0.1383894 & 0.0645758 & 0.0423387 & $0.0144351^{*}$ & $0.0233818^{*}$ & -0.0002454 \\
\hline & 0.0328977 & 0.014481 & 0.0104866 & 0.0067238 & 0.0120776 & 0.0078301 \\
\hline Employment protection legislation & 0.0074189 & -0.0297894 & -0.0032906 & 0.0164128 & 0.0005182 & -0.0027795 \\
\hline & 0.0634129 & 0.0230688 & 0.0166669 & 0.0106865 & 0.0191955 & 0.0150931 \\
\hline Control variables & & & & & & \\
\hline Deficit (\% of GOP) & -0.0362247 & -0.0081537 & $-0.0097112^{\# \#}$ & $-0.0022127^{*}$ & $-0.0149847^{\text {t.t }}$ & $-0.003135^{*}$ \\
\hline & 0.0051736 & 0.0024832 & 0.0017967 & 0.001152 & 0.0020693 & 0.0012314 \\
\hline Harmonised unemployment & 0.0047435 & 0.0051469 & 0.0014944 & -0.0017893 & -0.0027445 & $0.0039183^{* *}$ \\
\hline & 0.0081573 & 0.0035722 & 0.0025813 & 0.0016551 & 0.002973 & 0.0019416 \\
\hline GOP growth & -0.0040015 & 0.0014504 & 0.0025952 & -0.0031059 & -0.0031967 & -0.0021032 \\
\hline & 0.011433 & 0.0048871 & 0.0035362 & 0.0022673 & 0.0040727 & 0.0027212 \\
\hline Lagged dependent variable & no & no & no & no & no & no \\
\hline Time Trend & no & no & no & no & no & no \\
\hline Constant & yes & yes & yes & yes & yes & yes \\
\hline Method & gls & gls & gls & gls & gls & gls \\
\hline Time Dummies & yes & yes & yes & yes & yes & yes \\
\hline Country Dummies & yes & yes & yes & yes & yes & yes \\
\hline Years & $1985-2007$ & $1985-2007$ & $1985-2007$ & $1985-2007$ & $1985-2007$ & $1985-2007$ \\
\hline Observations & 240 & 261 & 262 & 262 & 262 & 240 \\
\hline Number of Countries & 15 & 15 & 15 & 15 & 15 & 15 \\
\hline Wald chi squared Stat & 1775.08 & 962.84 & 1352.11 & 3873.52 & 1077.95 & 1167.18 \\
\hline Prob $>c h i 2$ & 0 & 0 & 0 & 0 & 0 & 0 \\
\hline R Squared & n.a. & n.a & n.a & n.a & n.a & n.a \\
\hline$A R 1$ & no & no & no & no & no & no \\
\hline Tests for dummies and residuals & & & & & & \\
\hline Wald Chi squared (country dummies) & 566.68 & 320.82 & 691.56 & 1866.52 & 330.97 & 591.11 \\
\hline Prob $>$ chi2 & 0 & 0 & 0 & 0 & 0 & 0 \\
\hline Wald Chi squared (time dummies) & 33.06 & 18.31 & 32.41 & 5.8 & 60.55 & 25.51 \\
\hline Prob > chi2 & 0.0111 & 0.3698 & 0 & 0.9944 & 0 & 0 \\
\hline Tests when no dummies & & & & & & \\
\hline LR Test for heteroskedasticity & 169.63 & 150.29 & 413.42 & 797.47 & 303.13 & 336.78 \\
\hline Prob $>c h i 2$ & 0 & 0 & 0 & 0 & 0 & 0 \\
\hline Wooldridge test for autocorrelation & & & & & & \\
\hline$F(1,14)=$ & 395.444 & 277.337 & 17.847 & 73.907 & 128.327 & 55.332 \\
\hline$P r o b>F=$ & 0 & 0 & 0.0008 & 0 & 0 & 0 \\
\hline Multicollinearity & & & & & & \\
\hline Klein's Rule of Thumb & & & & & & \\
\hline Regression with DV & 0.5388 & 0.4763 & 0.3466 & 0.4569 & 0.4734 & 0.3832 \\
\hline Regression without DV & 0.1804 & 0.1804 & 0.1804 & 0.4569 & 0.1804 & 0.1804 \\
\hline VIF & No MC & No MC & No MC & No MC & No MC & No MC \\
\hline
\end{tabular}

Table 4: Feasible Generalised Least Squares on different active measures as \% of GDP 
This operationalization of the dependent variables is warranted on theoretical grounds, namely that we are interested in explaining the differences in levels across time and space, not in explaining the change in the dependent variables per se. Although the Hausman test suggested we should use fixed effects, tests for country dummies showed that they were significant with all dependent variables. This is not the case for all time dummies which inclusion is more justified with some dependent variables than others. Thus, we will also compare the results for fixed effects and random effects to investigate whether our results that the dependent variables are driven by different dynamics hold under all specifications.

Analysing Table 4 reveals that few explanatory variables are significant across regressions with different ALMPs. Deficit is the only case where this occurs, but this is hardly instructive as it is more appropriately conceived as a control variable. Wage coordination has a significant coefficient in all cases except for spending on Public Employment Services (PES). Even in this case, the size of the coefficient varies by a factor of four. The coefficient for GDP growth is not significant and varies in sign. Union density is not significant for employment incentives or supported rehabilitation while the presence of left wing parties in government, as shown by the coefficient for the "govparty" variable, has a significant negative correlation with these two dependent variables, and is significantly positively related to spending on PES. Similar variation in size, significance and direction of effects can be observed for the remaining independent variables. Deindustrialisation is only significant for direct job creation and the sign varies. Openness has a negative impact throughout but significance is only warranted for the case of PES. Harmonised unemployment is also only significant for PES and the sign varies again. Last but not least, none of the coefficients for overall EPL are significant and the sign varies depending on the dependent variable under consideration.

The Likelihood Ratio test of heteroskedasticity and Woodridge test for autocorrelation (Wooldridge 2002; Drukker 2003) revealed that the residuals using FGLS were both heteroskedastic and autocorrelated thereby violating the assumptions of spherical disturbances. This could mean that the different results for different dependent variables may be the result of violations of the assumptions on which the estimation procedure relies.

To address this issue, and following Beck (2001) as well as Beck and Katz (1995), I estimate the same models with Ordinary Least Squares (OLS) Panel Corrected Standard Errors (PCSE) which compute "variance-covariance matrices for panel data corrected for heteroskedasticity and contemporaneous correlation" (Martin and Swank 2004: 600). Given significant resilience in the evolution of my dependent variable, I also include a lagged dependent variable as well as a trend to capture trend effects. As the previous results were ambiguous with respect to model specification of fixed versus random effects, where the outcome of the Hausman test differed from the test of country dummies' significance, both random and fixed effects are run. Table 5 reports these results: there are non-trivial differences between the two specifications but in both cases the results differ for different dependent variables.

There are four potential problems with the 'Beck Katz standard': “absorption of crosssectional variance by unit dummies, absorption of time-series variance by the lagged dependent variable and period dummies, mis-specification of the lag structure, and neglect of parameter slope heterogeneity" (Plumper, Troeger et al. 2005: 327). As an alternative, one should rely on "Prais-Winsten transformation rather than the lagged dependent variable to eliminate serial correlation of errors" (ibid: 349). Thus, to ensure that autocorrelation is 
addressed, an Autocorrelation process of order 1 (AR1) was added to all the regressions. This estimation strategy therefore addresses both within and between panel correlations. The results for both fixed and random effects specifications of this estimation procedure are reported in Table 6: again there are important differences in the results for each dependent variable.

Panel Corrected Standard Errors assumes that "the disturbances are, by default, heteroskedastic and contemporaneously correlated across panels" (Stata 2010). If in fact different panels are independent and the observations within the panels are not, then one should run a regression with robust cluster standard errors, which is appropriate when "observations within cluster may not be treated as independent, but the clusters themselves are independent" (Gutierrez and Drukker 2003). In addition, regressions relying on robust cluster standard errors produce more unforgiving standard errors. Results for OLS regressions with robust clustered standard errors (Rogers 1993; Williams 2000) and random effects can be found in Table 7 .

Another potential issue with my approach is that so far I have only shown that level effects vary for different dependent variables, whereas some authors in the literature are interested in change effects. In addition, this ensures that the differences in the significant of the explanatory variables are not driven by issues of non-stationarity identified earlier. Thus, I also ran OLS regressions with PCSE taking the first difference of all my variables to look at the impact of a change in the independent variables on the change in my dependent variables. The results for this approach are shown in Table 8. Again there is a non-trivial variation in the significance and signs of the coefficients. Given the diversity of results depending on different specifications, this raises the question of what these results imply, which we address in the next sub-section. 


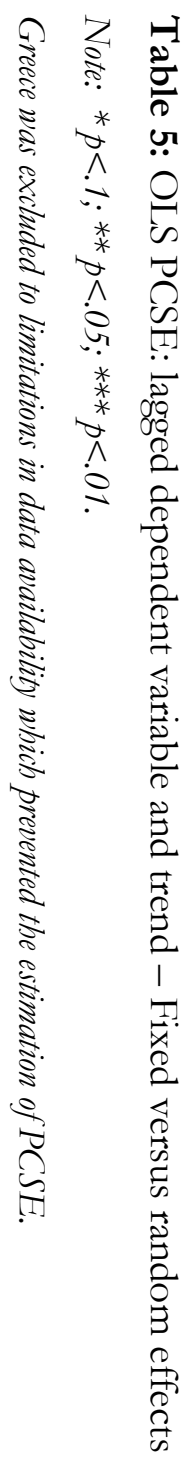

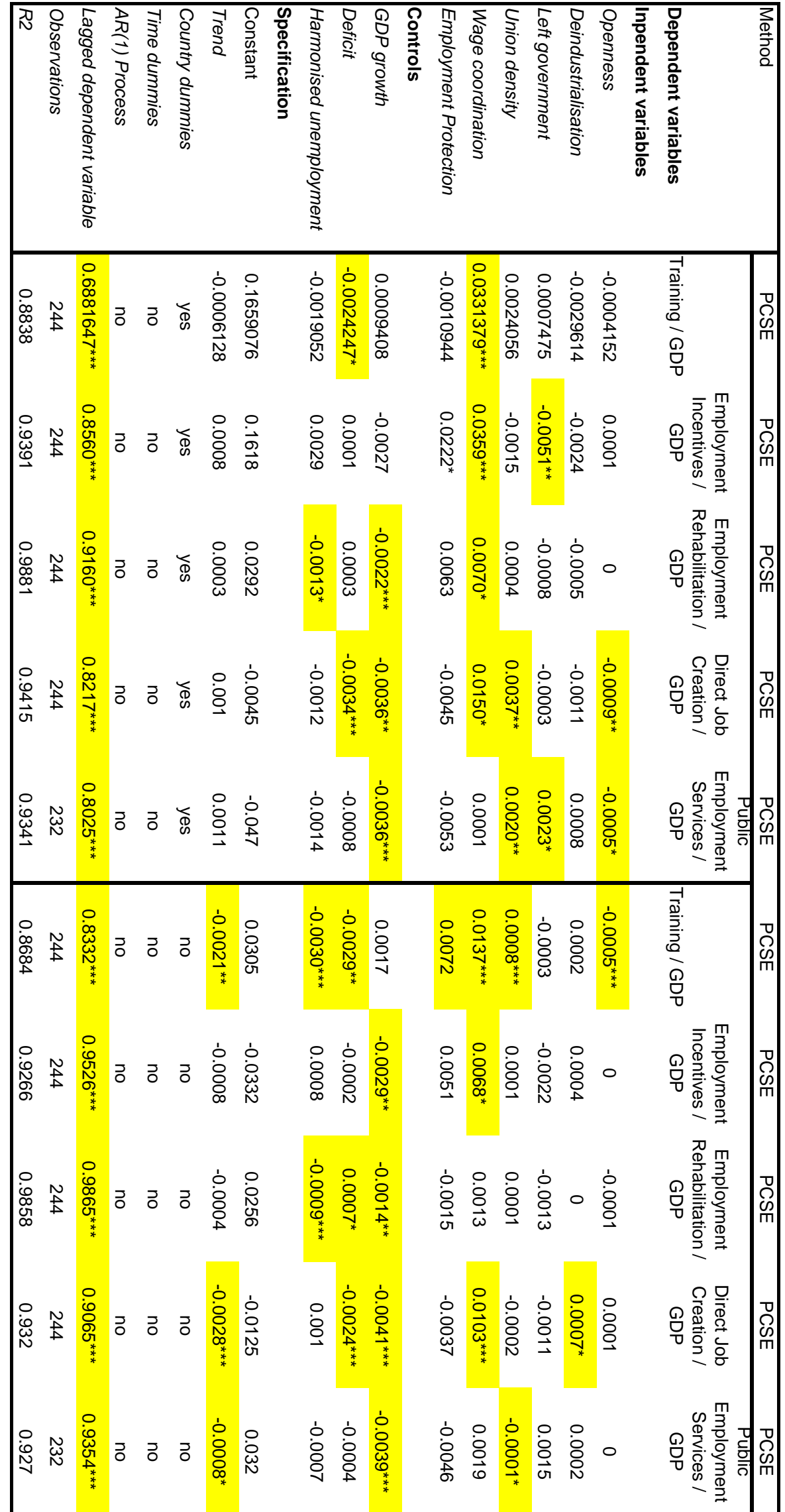




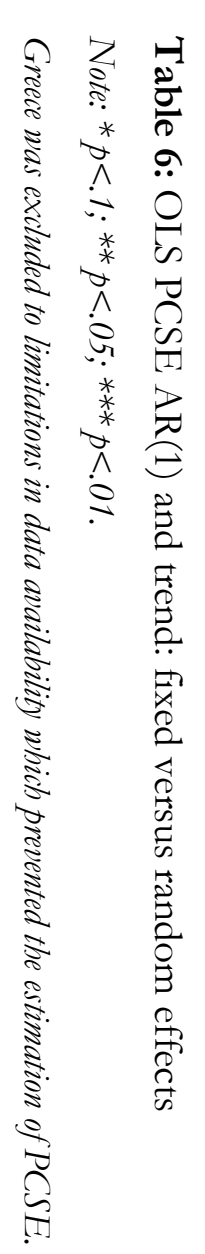

\begin{tabular}{|c|c|c|c|c|}
\hline 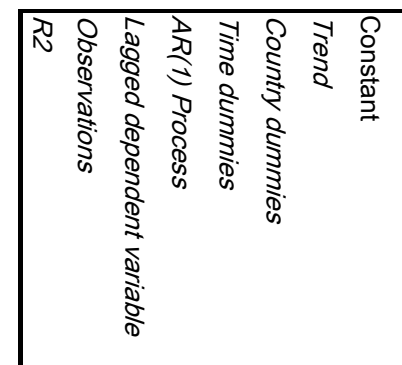 & 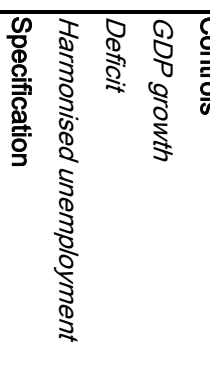 & 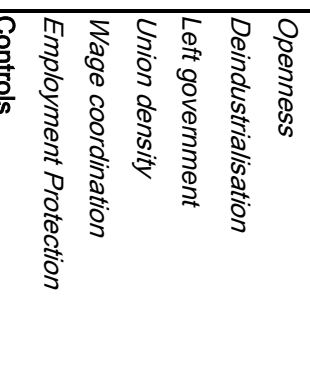 & 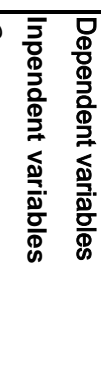 & $\overrightarrow{\overrightarrow{0}}$ \\
\hline 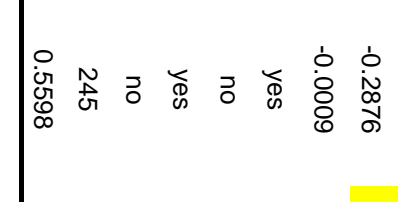 & ○ & 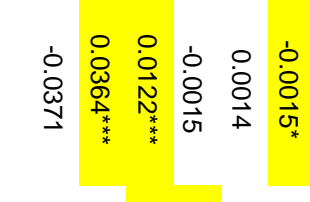 & & ర్ \\
\hline 总 N & 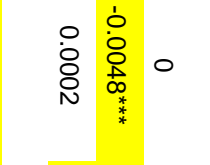 & 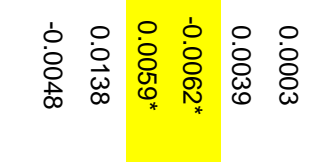 & & ర్ల \\
\hline 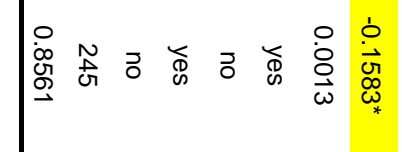 & 它客家 & 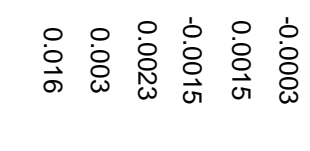 & & $\begin{array}{l}\text { D } \\
\text { D } \\
\text { m }\end{array}$ \\
\hline 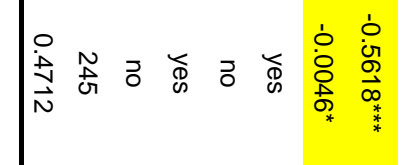 & 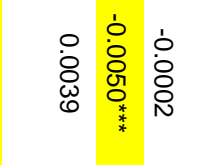 & 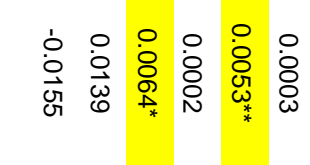 & & 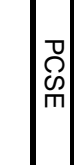 \\
\hline 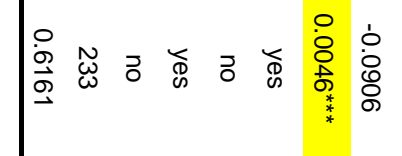 & 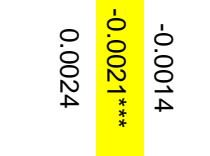 & 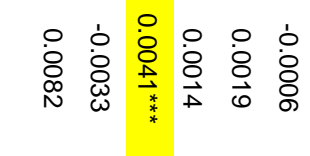 & & \\
\hline 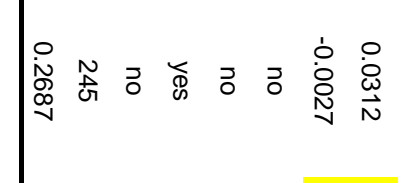 & 品㝘亶 & 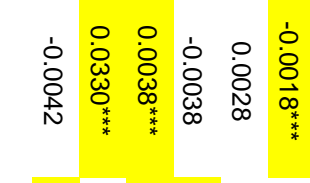 & & $\begin{array}{l}\stackrel{0}{0} \\
\text { Dn } \\
\text { m }\end{array}$ \\
\hline 㐫 & 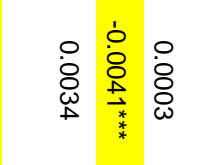 & 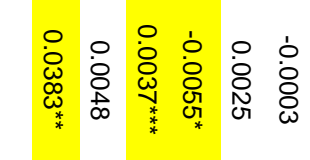 & & 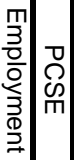 \\
\hline 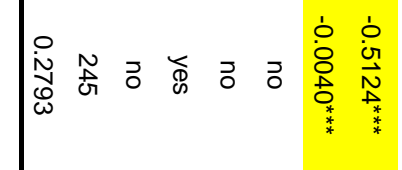 & 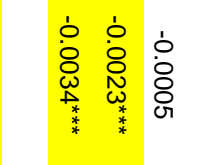 & 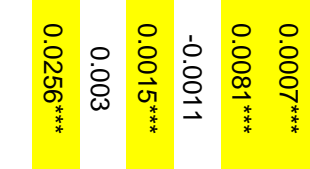 & & \\
\hline 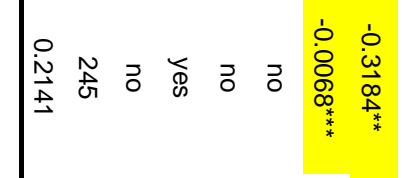 & 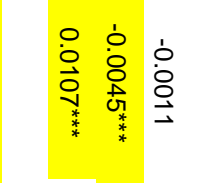 & 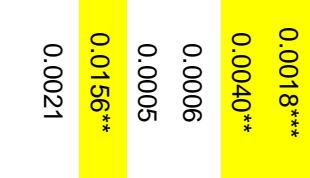 & & 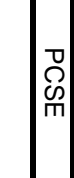 \\
\hline 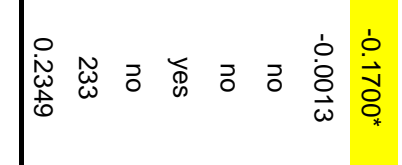 & 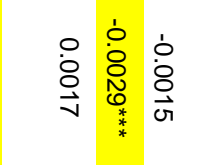 & 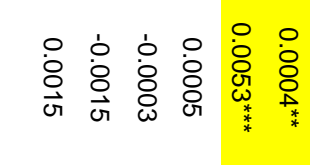 & & \\
\hline
\end{tabular}




\begin{tabular}{|c|c|c|c|c|c|}
\hline $\begin{array}{l}\text { Dependent variables } \\
\text { Inpendent variables }\end{array}$ & Training / GDP & $\begin{array}{c}\text { Employment } \\
\text { Incentives / GDP }\end{array}$ & $\begin{array}{c}\text { Employment } \\
\text { Rehabilitation / } \\
\text { GDP }\end{array}$ & $\begin{array}{c}\text { Direct Job } \\
\text { Creation / GDP }\end{array}$ & $\begin{array}{c}\text { Public } \\
\text { Employment } \\
\text { Services / GDP }\end{array}$ \\
\hline Openness & $-0.0025^{\star \star}$ & -0.0003 & 0.0012 & $0.0023^{\star *}$ & 0.0012 \\
\hline Deindustrialisation & 0.0053 & 0.0038 & $0.0125^{\star *}$ & $0.0073^{*}$ & $0.0068^{\star *}$ \\
\hline Left government & -0.0064 & -0.0005 & -0.0039 & -0.0011 & 0.0051 \\
\hline Union density & $0.0046^{\star \star *}$ & $0.0044^{*}$ & 0.0012 & 0.0002 & -0.0008 \\
\hline Wage coordination & $0.0610^{\star *}$ & -0.0004 & 0.0066 & $0.0376^{\star \star}$ & -0.0012 \\
\hline Employment Protection & 0.0028 & $0.0554^{*}$ & $0.0507^{*}$ & 0.0234 & -0.0071 \\
\hline \multicolumn{6}{|l|}{ Controls } \\
\hline GDP growth & 0.0122 & 0.0039 & -0.0057 & 0.0022 & -0.0048 \\
\hline Deficit & $-0.0113^{\star \star \star}$ & -0.0112 & $-0.0077^{\star}$ & $-0.0084^{\star}$ & $-0.0082^{\star \star}$ \\
\hline Harmonised unemployment & -0.0022 & 0.0045 & -0.0114 & $0.0177^{\star *}$ & -0.0031 \\
\hline \multicolumn{6}{|l|}{ Specification } \\
\hline Constant & -0.1935 & -0.5147 & $-0.7893^{\star *}$ & $-0.6984^{\star \star}$ & -0.2228 \\
\hline Trend & -0.0025 & 0.0061 & -0.0059 & $-0.0091^{\star \star}$ & -0.0032 \\
\hline Country dummies & no & no & no & no & no \\
\hline Time dummies & no & no & no & no & no \\
\hline$A R(1)$ Process & no & no & no & no & no \\
\hline Lagged dependent variable & no & no & no & no & no \\
\hline Observations & 261 & 262 & 262 & 262 & 240 \\
\hline$R 2$ & 0.4976 & 0.3742 & 0.481 & 0.5286 & 0.4019 \\
\hline
\end{tabular}

Table 7: Robust cluster with random effects and a trend

Note: ${ }^{*} p<.1 ; * * p<.05 ; * * * p<.01$.

\begin{tabular}{|c|c|c|c|c|c|}
\hline Dependent variables & $\Delta$ (Training / GDP) & $\begin{array}{c}\Delta \text { (Employment } \\
\text { Incentives / GDP) }\end{array}$ & $\begin{array}{c}\Delta \text { (Employment } \\
\text { Rehabilitation / } \\
\text { GDP) }\end{array}$ & $\begin{array}{c}\Delta \text { (Direct Job } \\
\text { Creation / GDP) }\end{array}$ & $\begin{array}{c}\Delta \text { (Public } \\
\text { Employment } \\
\text { Services / GDP) }\end{array}$ \\
\hline \multicolumn{6}{|l|}{ Inpendent variables } \\
\hline$\Delta$ Openness & -0.0000279 & -0.0004383 & -0.0001861 & $-0.0011089^{* * *}$ & $-0.0007371^{* * *}$ \\
\hline$\Delta$ Deindustrialisation & -0.0023811 & -0.0024044 & 0.0005413 & -0.0005606 & $0.0018451^{* *}$ \\
\hline$\Delta$ Left government & 0.0017307 & $-0.0066131^{* * *}$ & -0.0008754 & -0.0009167 & $0.0012798^{* *}$ \\
\hline$\Delta$ Union density & -0.0006216 & $-0.0030746^{\star}$ & 0.0005157 & 0.0005275 & 0.0010135 \\
\hline$\Delta$ Wage coordination & 0.0221641 & $0.0417579^{\star * *}$ & $0.0085754^{*}$ & 0.0091327 & $0.0060742^{\star \star \star}$ \\
\hline$\Delta$ Employment Protection & 0.0173676 & $0.0288111^{\star *}$ & $0.009211^{* *}$ & -0.0008372 & -0.0073052 \\
\hline \multicolumn{6}{|l|}{ Controls } \\
\hline GDP growth & 0.0000264 & -0.0015281 & -0.0009716 & $-0.0035841^{*}$ & -0.001066 \\
\hline$\Delta$ Deficit & -0.0005577 & 0.0007745 & -0.0001065 & -0.001333 & $-0.0007007^{*}$ \\
\hline$\Delta$ Harmonised unemployment & -0.0027822 & $0.005562^{* * *}$ & 0.00000848 & -0.0003913 & -0.0006698 \\
\hline \multicolumn{6}{|l|}{ Specification } \\
\hline Trend & no & no & no & no & no \\
\hline Lagged Dependent Variable & 0.0392089 & 0.0303461 & 0.0250918 & $0.2775653^{\star * \star}$ & $-0.1163971^{\star *}$ \\
\hline Time Dummies & yes & yes & yes & yes & yes \\
\hline Country Dummies & yes & yes & yes & yes & yes \\
\hline R-Squared & 0.1422 & 0.2731 & 0.2844 & 0.3095 & 0.2161 \\
\hline Observations & 257 & 260 & 260 & 260 & 236 \\
\hline
\end{tabular}

Table 8: OLS PCSE on the first difference of ALMPs

Note: ${ }^{*} p<.1 ; * * *<.05 ; * * * p<.01$. 


\section{D: Discussion of results}

The previous section established forcefully that regardless of the estimation method used, there are important differences between different types of ALMPs with respect to the significance, sign and magnitude. Differences in magnitude, provided that they are small, are not particularly problematic. If they are large, then relying on aggregate ALMPs may lead to infer a medium average effect whereas some programs are only marginally affected by the independent variable under consideration while it has large effects on others.

Differences in the significance of coefficients for different dependent variables are quite important because then relying on aggregate ALMPs may mean we wrongly infer a significant relationship between two variables where there is in fact none or fail to identify a significant relationship which exists (that is there is a risk of both type I and type II errors). To get a bigger picture of what is going on with respect to the variation in significance of different coefficients depending on the regression, sixteen specifications were run (four methods across four different specifications, see appendix table A1). Note that the results of the first difference are not analysed because we are interested in the different impact of the independent variables on the levels of distinct ALMPs.

Table 9 displays the type of regression that found coefficients to be significant. As an illustration, openness was not found to be significant for employment incentives in any of the specifications whereas it was found to be significant under specification $C, D, H, K$, and $L$ for employment rehabilitation. The coefficients that were found to be significant at least once in each type of regression method (FGLS, PCSE with a lagged dependent variable, PCSE with an autoregressive process of order 1, and Robust clustered standard errors) are highlighted. This demonstrates unequivocally that there are important differences in what are significant determinants of different ALMPs. For instance, partisanship clearly has no impact on Direct Job Creation while it may be significantly related to employment incentives.

However, this says nothing about the direction of the relation. Differences in signs are crucially important because they indicate different direction of causation which can then imply completely different theories underlying the changes in policies we observe. For instance, if higher union density leads to lower spending on one policy but to higher spending on another then this means that the degree of inclusiveness or strength that union density is supposed to proxy has different and even opposite effects on the different types of ALMPs. This then has important implications for the validity of studies of that specific case (i.e.: that rely on ALMPs and union density) but also for broader theories of which this is only a case (i.e.: for theories that do not rely on ALMPs but look at the effects of unions on policies such as revitalisation strategies). The same applies to the effect of partisanship which may for instance be different for employment incentives and direct job creation.

To address this shortcoming we map the direction of causation for coefficient results which are found significant in each regression. This is presented in Table 10. The impact of openness on training is clearly negative, while it has no impact on Employment incentives, and ambiguous effects on the other ALMPs. Thus, previously conflicting results are partly driven by different dynamics within ALMPs (Training versus employment incentives) and may be the result of different regression methods yielding different results. 


\begin{tabular}{|c|c|c|c|c|c|}
\hline & Training / GDP & $\begin{array}{c}\text { Employment } \\
\text { Incentives / GDP }\end{array}$ & $\begin{array}{c}\text { Employment } \\
\text { Rehabilitation / GDP }\end{array}$ & $\begin{array}{c}\text { Direct Job Creation / } \\
\text { GDP }\end{array}$ & $\begin{array}{l}\text { Public Employment } \\
\text { Services / GDP }\end{array}$ \\
\hline Openness & CDFHIJKLOP & & CDHKL & CDEGKLOP & ABCDEGKLN \\
\hline Deindustrialisation & CDEGL & $C D$ & CDKLOP & ACDIKOP & CDKLOP \\
\hline Left Government & & BEGIJKL & $A B$ & & ABE \\
\hline Union density & ABCDEFGHIJKLOP & ABCDIKLOP & CDKL & ABEGIMN & ABCDEGIJMN \\
\hline Wage coordination & ABCDEFGHIJKLMNOP & ABEGHMN & ABEG & ABCDEFHKMOP & \\
\hline $\begin{array}{l}\text { Employment Protection } \\
\text { Legislation }\end{array}$ & ABCDEFGHIJKP & CDGKLOP & CDGKLOP & CD & \\
\hline \multicolumn{6}{|l|}{ Controls } \\
\hline GDP growth & CDJL & $\mathrm{F}$ & ADEF & EFGH & AEFH \\
\hline Deficit & ABCDEFGHJMNOP & ABCDIJKLN & ABCDFIJKLOP & \multicolumn{2}{|c|}{ ABCDEFGHIJKLMOP ABCDIJKLOP } \\
\hline Harmonised unemployment & $\mathrm{FH}$ & CDGL & ACDEFHIKL & CDKLOP & $\mathrm{ACD}$ \\
\hline \multicolumn{2}{|l|}{ Notes } & \multicolumn{4}{|c|}{ all types of estimations } \\
\hline & & $a, b, c, d$ & FGLS & \multicolumn{2}{|c|}{$\mathrm{FE} A, B, E, G, I, J, M, N$} \\
\hline & & $e, f, g, h$ & OLS PCSE LDV & \multicolumn{2}{|c|}{$\mathrm{RE} C, \mathrm{D}, \mathrm{F}, \mathrm{H}, \mathrm{K}, \mathrm{L}, \mathrm{O}, \mathrm{P}$} \\
\hline & & $\mathrm{i}, \mathrm{j}, \mathrm{k}, \mathrm{l}$ & OLS PCSE AR1 & \multicolumn{2}{|c|}{ TREND A,C,E,F,I,K,M,O } \\
\hline & & $m, n, o, p$ & RC CLUSTER & \multicolumn{2}{|c|}{ TIME DUMMIES B,D,G,H,J,L,N,P } \\
\hline
\end{tabular}

Table 9: Variation of coefficient significance under different methods.

Deindustrialisation, where it is significant, has a positive relation with employment rehabilitation, direct job creation and Public Employment Services (PES), while the impact is ambiguous on training and only positively significant with two occasions for employment incentives. Partisanship has no significant relation with training or direct job creation and ambiguous effect on PES. The negative relation between partisanship and employment incentives imply that left leaning governments spend less on employment incentives than right wing governments. Union density has a positive effect on training under almost all specifications, while the sign is not stable for employment incentives and only few coefficients are significant for employment rehabilitation. The positive relation between density and direct job creation as well as PES is found in 7 out of the 16 specifications, providing mixed results.

Wage coordination's positive impact on training represents the most significant finding of this paper as it has a positive impact under all specifications. In other words, the higher the degree of wage coordination, the higher the level of expenditures on training targeted at the unemployed. The positive relation is less consistent with direct job creation and employment incentives, and on the basis of these results one should doubt that wage coordination has any effect on employment rehabilitation or PES. The effect of Employment Protection Legislation which is key to the on-going theorisation of the insider-outsider model of labour market policy only has a significant effect on employment incentives and rehabilitation, but, in contradiction with Rueda's (2007) findings, the effect is positive not negative. Last but not least, unemployment does not have a consistent effect across different specifications but the existing results suggest that it is positively related to employment incentives and direct job creation and negatively related to employment rehabilitation. 


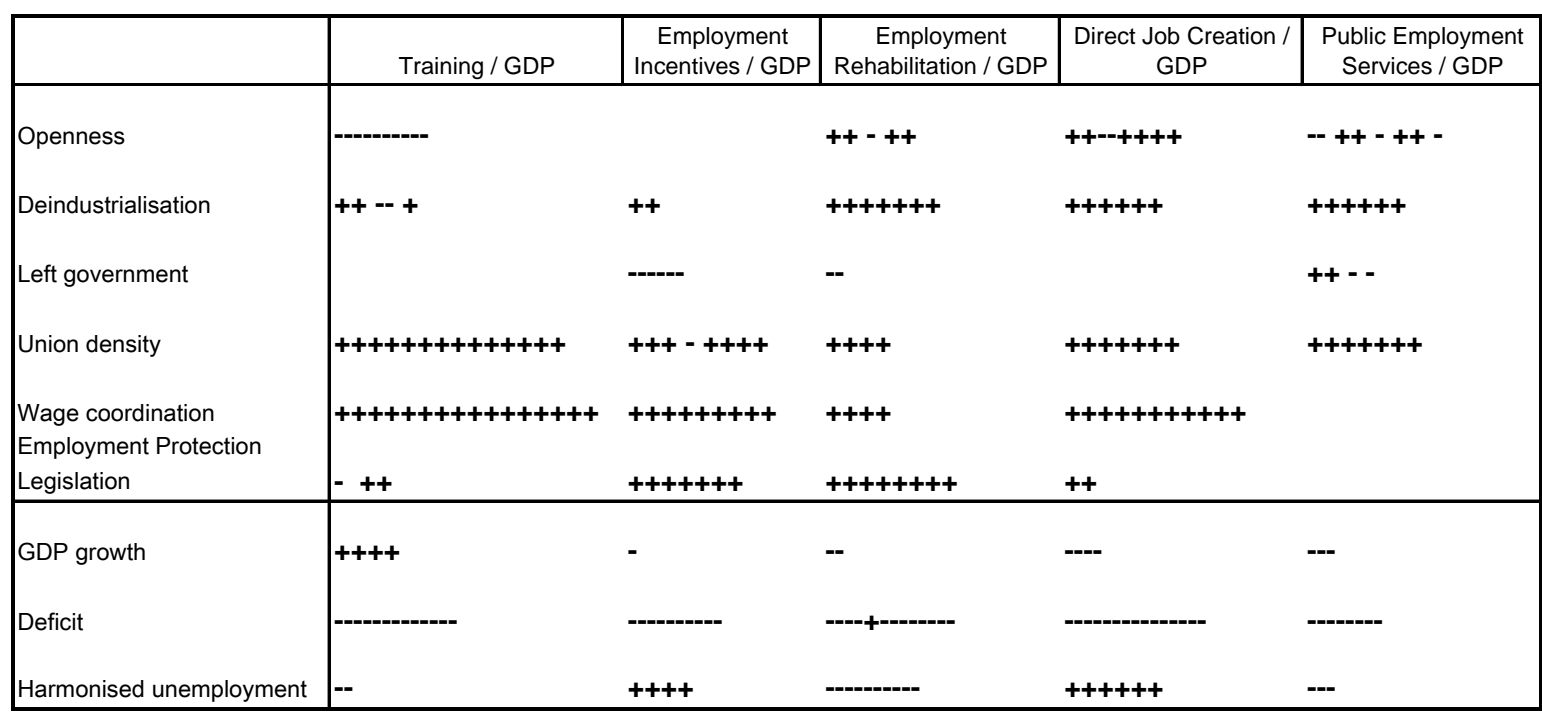

Table 10: Direction of the relation between variables under different specifications

\section{Conclusion}

Existing studies of the determinants of ALMPs have found sometimes quite different effects of key explanatory variables. However, the qualitative literature on activation processes underscores the distinctiveness of the determinants of different ALMPs. This paper questioned whether existing approaches relying on aggregate data on ALMPs are appropriate.

Using different estimation methods and different specifications of the dependent variables I showed how the determinants of ALMPs identified in the literature review have different relations to different components of ALMPs. Indeed the magnitude, sign and significance of the coefficients varied significantly between different ALMPs. This result was robust to different estimation method and specification of the dependent variable.

The analysis of the determinants of disaggregated ALMPs revealed some new insights which may partly reconcile previously contradictory results. First, variables are much more often significant overall in the model of spending on training than of other variables, which raises the question as to whether training is driving some of the results relying on aggregate ALMPs. Thus, other dynamics may be driving the cross national evolution of spending on other ALMPs and these remain to be fully investigated.

Second, if partisanship matters at all, it suggests that right wing parties spend more on employment incentives than left wing parties. This conflicts with previous findings and is consistent with the position that traditional socialist parties in Europe as in France have taken towards certain activation processes. Union density is positively related most clearly to training, in line with the contention that more inclusive unions will support policies that also favour the unemployed. The positive association between training and both direct job 
creation as well as PES is consistent with revitalisation where unions support policies that may extend their membership base.

Third, wage coordination is strongly positively related to training, and to a lesser extent to direct job creation and employment incentives (note that we do not count as strong results, those where the coefficients are not significant in at least four different regression methods see Table 9). This is consistent with the notion that training, by raising the productivity of low skill unemployed workers, makes it possible to coordinate wages to a larger extent. Direct job creation might mechanically increase wage coordination by creating jobs in the public sector. Wage coordination may also mitigate the downwards wage effects that employment incentives may have on the reservation wage in the absence of coordination, which could be a potential explanation for the positive relation between wage coordination and employment incentives.

Fourth, employment protection has no relation to training, direct job creation or PES. Where it is significant, it is positively related to employment incentives and employment rehabilitation. This contradicts the notion that employment protection of labour market insiders is negatively related to all types of ALMPs and opens the possibility that systems with higher employment protection also spend more on certain active measures. In other words, insiders' institutions may also benefit outsiders.

Last but not least, deindustrialisation is not a strong explanation behind the training and employment incentives expenditures which represents in the period 1985-2007 more than $50 \%$ of expenditures in Scandinavia and in the Southern clusters. Openness has a negative effect on training, no effect on employment incentives and a weak as well as ambiguous effect on other ALMPs. Thus, it is not contentious to conclude that at the very least, more open economies do not spend more on training.

On the basis of these results, it is clear that relying on aggregate ALMPs as a dependent variable is potentially problematic and that analysing the interaction between different ALMPs and key explanatory variables may be a potentially valuable avenue for further research.

\footnotetext{
1 This paper benefited from valuable comments from participants at the Recwowe doctoral workshop in Menton (October 2010) and at the European Institute Lunch Seminars (November 2010). The author is particular grateful for feedback received from Bob Hancke, Marco Simoni, Giulano Bonoli, Vassilis Monastiriotis and Abel Bojar.

2 Most often this includes a mixture of raising "work availability requirements", "make work pay policies", and increasing "employability" (see OECD website: http://www.oecd.org/document/5/0,3343, en $264933927 \quad 38938757 \quad 1 \quad 1 \quad 1 \quad$ 1,00.html
}

${ }^{3}$ For reason of parsimony, interaction effects between variables are not specifically considered. 
${ }^{4}$ Franzese and Hays (2006) only find it significant when ALMPs are weighted with unemployment but not when it is weighted with GDP.

${ }^{5}$ Subsequently the OECD has undertaken a harmonisation exercise to ensure its data collected prior to 1998 was consistent with the new classification.

${ }^{6}$ Country and time dummies are not present in all specification as we run both random and fixed effects as well as time dummies and a trend, depending on the specification 


\section{References}

Armingeon, K. (2005). " OECD, EU and Active Labour Market Policy" Presented at the Annual meeting of the international studies association, Honululu, Hawai.

Armingeon, K. (2007) "Active labour market policy, international organisation and domestic politics." Journal of European Public Policy 14(6): 905-932.

Armingeon, K., M. Gerger, et al. (2008). Comparative political dataset 1960-2006.

Barbier, J.-C. (2001). Welfare to work policies in Europe. The current Challenges of activation policies. Paris, Centre d'Etude de l'Emploi.

Barbier, J.-C. and W. Ludwig-Mayerhofer (2004). "The many worlds of activation." European Societies 6(4): 423-437.

Beck, N. (2001). "Time series-cross section data: What have we learned in the past few years?" Annual review of political science 4: 271-293.

Beck, N. and J. Katz (1995). "What to do (and not to do) with time series crosssection data." American Political Science Review 89(3): 634-647.

Boix, C. (1998). Political parties, growth and equality : conservative and social democratic economic strategies in the world economy. Cambridge, U.K ; New York, N.Y., Cambridge University Press.

Bonoli, G. (2008). The political economy of activation. Explaining cross national variation in active labour market policy. Annual ESPAnet conference. Helsinki.

Bonoli, G. (2010). "The political economy of active labour market policy." Politics \& Society 38(4): 435-457.

Calmfors, L., A. Forslund, et al. (2001). "Does active labour market policy work? Lessons from the Swedish experiences." Swedish Economic Policy Review 85: 61 124.

Cameron, D. (1978). "The expansion of the public economy: A comparative analysis." American Political Science Review 72(4): 1243-1261.

Clegg, D., P. Graziano, et al. (2010). Between sectionalism and revitalisation: Trade unions and activation policies in Europe. Working Papers on the Reconciliation of Work and Welfare in Europe, RECWOWE.

Dahlström, c., J. Lindvall, et al. (2009). Social Protection strategies in efficient and inefficient states. QoG Working paper series, University of Gothenburg.

De la Porte, C. and P. Nanz (2003). OMC - a deliberative democratic mode of governance? The cases of employment and pensions. ESPANET conference "Changing European Societies - the role for Social Policy. Copenhagen.

Drukker, D. M. (2003). "Testing for serial correlation in linear panel-data models." Stata Journal 3: 168-177.

Ebbinghaus, B. (2006). Trade union movements in post industrial welfare states: Opening up to new social interests? The politics of Post-industrial Wefalre States. 
Adapting post war policies to new social risks. K. Armingeon and G. Bonoli. London, Routledge.

Esping-Andersen, G. (1990). The three worlds of welfare capitalism. Cambridge, Polity.

Franzese, R. and J. Hays (2006). "Strategic interaction among EU governments in Active Labour Market Policy making: Subsidiarity and policy coordination under the European Employment Strategy." European Union Politics 7(2): 167-189.

Garrett, G. (1995). "Capital Mobility, Trade and the domestic Politics of Economic Policy." International Organisation 49(4): 657-687.

Garrett, G. (1998). Partisan politics in the global economy. Cambridge, UK ; New York, Cambridge University Press.

Gaston, N. and G. Rajaguru (2008). "The rise (and fall) of labour market programmes: Domestic vs. global factors." Oxford Economic Papers 60(4): 619-648.

Grubb, D. and A. Puymoyen (2008). Long time series for public expenditure on labour market programs. OECD social, employment migreation papers. Paris, OECD.

Gujarati, D. N. (2003). Basic econometrics. Boston, London, McGraw-Hill.

Gutierrez, R. and D. Drukker. (2003). "Reference for cluster-correlated robust variance calculation." From http://www.stata.com/support/faqs/stat/robust ref.html.

Hausman, J. (1978). "Specification tests in Econometrics." Econometrica 46: 1251 1271.

Huber, E. and J. D. Stephens (2001). Development and crisis of the welfare state. Parties and Policies in Global Markets. Chicago, University of Chicago Press.

Huo, J., M. Nelson, et al. (2008). "Decommodification and activation in social democratic policy: resolving the paradox." Journal of European Social policy 18: 520 .

Iversen, T. and T. Cusack (1998). The causes of welfare state expansion: deindustrialisation or globalisation? Berlin, WZB.

Janoski, T. and A. M. Hicks (1994). The comparative political economy of the welfare state. Cambridge, UK ; New York, NY, USA, Cambridge University Press.

Katzenstein, P. (1985). Small States in World Markets. Ithaca, NY and London, Cornell University press.

Korpi, W. (1978). The working class in welfare capitalism : work, unions and politics in Sweden. London, Routledge and Kegan Paul.

Martin, C., J. and D. Swank (2004). "Does the Organization of Capital Matter? Employers and Active Labor Market Policy at the National and Firm Levels." American Political Science Review 98(4): 593-611. 
Martin, J. and D. Grubb (2001). "What works and for whom: A review of OECD countries' experiences with active labour market policies." Swedish Economic Policy Review 8: 9-56.

Nelson, M. (2006). Unionized Workers And Support for Active Labor Market Policies. Fifteenth International Conference of the Council for European Studies Chicago. Chicago.

Nelson, M. (2009). "An application of the estimated dependent variable approach: Trade union members' support for active labour market policies and insider-outsider politics." International Journal of Public Opinion Research 21(2).

Plumper, T., V. Troeger, et al. (2005). "Panel data analysis in comparative politics: Linking method to theory." European Journal of Political research 44(2).

Rodrik, D. (1998). "Why do more open Economies have larger governments?" Journal of Political Economy 106(October): 997-1032.

Rogers, W. H. (1993). "Regression standard errors in clustered samples." Stata Technical Bulletin 13: 19-23.

Rueda, D. (2006). "Social democracy and active labour market policies: Insiders, outsiders and the politics of employment promotion." British Journal of Political Science 36: 385-406.

Rueda, D. (2007). Social democracy inside out. Partisanship and labour market policy in industrialised democracies. Oxford.

Stata. (2010). "Stata 11 help for xtpcse." from

http://www.stata.com/help.cgi?xtpcse.

Swank, D. (2007). The political economy of labour market policy reform in European and non european capitalist democracies. Annual meeting of the American Political Science Association. Chicago.

Swank, D. and C. Martin (2001). "Employers and the welfare state - the political economic organisation of firms and social policy in contemporary capitalist democracies." Comparative political studies 34(8): 889-923.

Swank, D. and C. Martin (2010). The political foundations of redistribution and equality in postindustrial capitalist democracies. Annual Meeting of the American Political Science Association. Toronto.

Swenson, P. (1991). "Bringing Capital back in, or Social Democracy Reconsidered: employer power, cross class alliances, and centralisation of industrial relations in Denmark and Sweden." World politics 43(4): 513-.

Swenson, P. (2002). Capitalists against markets: the making of labor markets and welfare states in the United States and Sweden. New York, Oxford University Press.

Taylor-Gooby, P. (2004). New risks, New welfare. The transformation of the European Welfare State. Oxford and New York, Oxford University Press.

Torfing, J. (1999). "Workfare with welfare: recent reforms of the Danish welfare state." Journal of European Social policy 9: 5-28. 
Traxler, F. and B. Brandl (2009). The Economic Effects of Collective Bargaining Coverage. Geneva, International Labour Office; Global Union Research Network (GURN).

Van Vliet, O. and F. Koster (2008). Europeanisation and the political economy of active labour market policies. NIG Annual Work Conference Enschede.

Williams, R. L. (2000). "A note on robust variance estimation for cluster correlated data." Biometrics 56: 645-646.

Wooldridge, J. M. (2002). Econometric analysis of cross section and panel data. Cambridge, MIT press.

Zeitlin, J. and P. Pochet (2005). The Open Method of Coordination in Action. Berne, Peter Lang. 


\section{Appendix}

Table A1: List of model specifications and estimation method

Code Estimation method: fixed versus random effects and trend versus time dummies.

A Feasible Generalised Least Squares, Fixed Effects, trend

B Feasible Generalised Least Squares, Fixed Effects, time dummies

C Feasible Generalised Least Squares, Random Effects, trend

D Feasible Generalised Least Squares, Random Effects, time dummies

E Panel Corrected Standard Errors, Lagged dependent variable, Fixed Effects, trend

F Panel Corrected Standard Errors, Lagged dependent variable, Random Effects, trend

G Panel Corrected Standard Errors, Lagged dependent variable, Fixed Effects, time dummies

H Panel Corrected Standard Errors, Lagged dependent variable, Random Effects, time dummies

I Panel Corrected Standard Errors, Autoregressive process (1), Fixed Effects, trend

J Panel Corrected Standard Errors, Autoregressive process (1), Fixed Effects, time dummies

K Panel Corrected Standard Errors, Autoregressive process (1), Random Effects, trend

L Panel Corrected Standard Errors, Autoregressive process (1), Random Effects, time dummies

M Robust clustered standard errors - Fixed Effects, trend

$\mathrm{N}$ Robust clustered standard errors - Fixed Effects, time dummies

O Robust clustered standard errors - Random Effects, trend

P Robust clustered standard errors - Random Effects, time dummies 


\section{Recent titles in this series}

download at http://www.socialpolicy.ed.ac.uk/recwowepudiac/working papers/

\begin{tabular}{|c|c|c|}
\hline \multicolumn{3}{|c|}{ Working Papers 2011} \\
\hline $02 / 11$ & $\begin{array}{l}\text { Christian Albrekt } \\
\text { Larsen, } \\
\text { Patrik Vesan }\end{array}$ & $\begin{array}{l}\text { Public Employment Services, Employers and the } \\
\text { failure of placement of low-skill workers in six } \\
\text { European countries }\end{array}$ \\
\hline $01 / 11$ & Janine Leschke & $\begin{array}{l}\text { Flexible working lives and pension coverage in } \\
\text { Europe with a focus on women: Lessons to be } \\
\text { learned by Germany? }\end{array}$ \\
\hline
\end{tabular}

Working Papers 2010

15/10 Caroline de la Porte

$\begin{array}{ll}\text { 14/10 } & \text { Heejung Chung, } \\ \text { Wim van Oorschot }\end{array}$

13/10 Marta lbáñez

\begin{tabular}{lll}
\hline $12 / 10$ & $\begin{array}{l}\text { Eric Crettaz, } \\
\text { Giuliano Bonoli }\end{array}$ & $\begin{array}{l}\text { Why Are Some Workers Poor? The Mechanisms that } \\
\text { Produce Working Poverty in a Comparative } \\
\text { Perspective }\end{array}$ \\
\hline $11 / 10$ & $\begin{array}{l}\text { Sophie Jacquot, } \\
\text { Clemence Ledoux, } \\
\text { Bruno Palier }\end{array}$ & $\begin{array}{l}\text { European resources in the field of reconciliation } \\
\text { between paid work and private life }\end{array}$ \\
\hline $10 / 10$ & $\begin{array}{l}\text { Giuliano Bonoli, } \\
\text { Karl Hinrichs }\end{array}$ & $\begin{array}{l}\text { Statistical Discrimination and Employers' } \\
\text { Recruitment Practices for Low-Skilled Workers }\end{array}$ \\
\hline $09 / 10$ & Sascha Zirra & $\begin{array}{l}\text { Domestic Europeanization - Institutional } \\
\text { Entrepreneurs and Welfare State Change }\end{array}$ \\
\hline $08 / 10$ & $\begin{array}{l}\text { Marek Naczyk, } \\
\text { Bruno Palier }\end{array}$ & $\begin{array}{l}\text { Complementing or replacing old age insurance? The } \\
\text { growing importance of funded pensions in the French } \\
\text { pension system }\end{array}$
\end{tabular}

REC-WP

Working Papers on the Reconciliation of Work and Welfare in Europe
State of the art. Overview of concepts, indicators and methodologies used for analyzing the social OMC

Employment insecurity of European individuals during the financial crisis. A multi-level approach

Fertility, Female Participation in Employment and Reconciliation Policies in Spain

Why Are Some Workers Poor? The Mechanisms that Produce Working Poverty in a Comparative Perspective

European resources in the field of reconciliation

Statistical Discrimination and Employers'

Domestic Europeanization - Institutional

Complementing or replacing old age insurance? The pension system

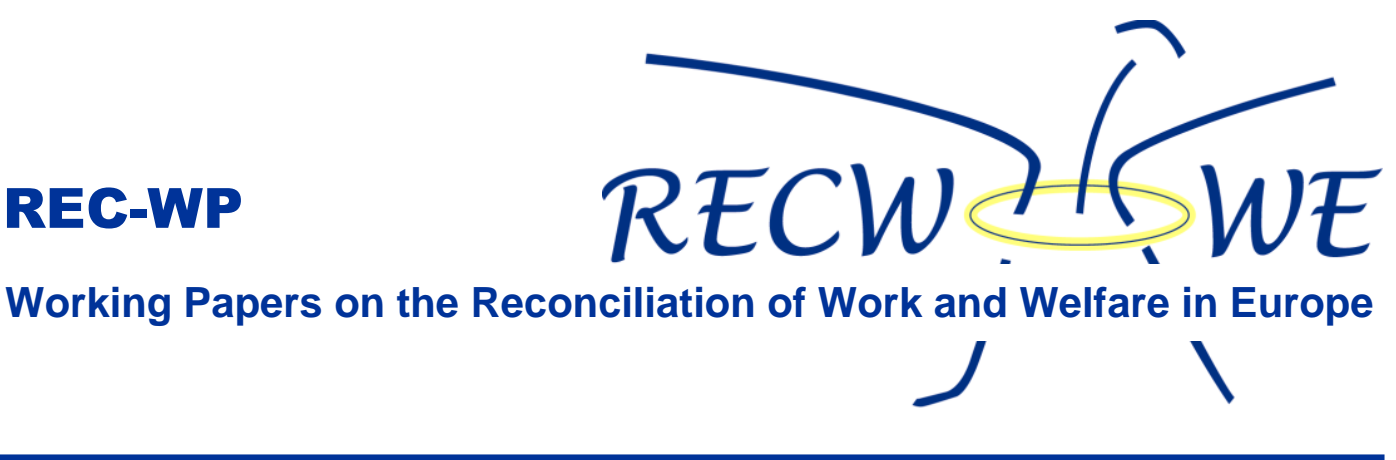

